\title{
ERNST CASSIRER'S SUI GENERIS LOGICISM: ON THE RECEPTION OF THE LOGICIST THESIS AND ITS ROLE IN SUBSTANZBEGRIFF UND FUNKTIONSBEGRIFF
}

\author{
Lucas Alessandro Duarte Amaral \\ Doutorando em Filosofia (CAPES) pela PUC-SP \\ lucasalessandro@hotmail.com \\ lucasadamaral@gmail.com
}

\begin{abstract}
In this article we aim to explore some aspects on Ernst Cassirer's logicism. In order to fulfill such task, we will initiate our analyses with the reception of the logicist thesis in the origins of Cassirer's theoretical context, showing firstly the importance assumed by the mentioned thesis in two of its most important figures (Frege and Russell) and, secondly, to show Cassirer's critique on then and his defense on Dedekind. Then, we will resume the role played by Cassirer's predecessors in Marburg (Cohen and Natorp) and their innovators Transcendental Method and Transcendental Logic on the sui generis Logicism of our author.
\end{abstract}

Keywords: Logicism. Neo-Kantianism of Marburg. Cassirer's early epistemology.

\section{O LOGICISMO SUI GENERIS DE ERNST CASSIRER: SOBRE A RECEPÇÃO DA TESE LOGICISTA E SEU PAPEL EM SUBSTANZBEGRIFF UND FUNKTIONSBEGRIFF}

Resumo: Pretendemos neste artigo explorar alguns aspectos em torno ao logicismo de Ernst Cassirer. Para tanto, iniciaremos nossa análise com a recepção da tese logicista nas origens do contexto teórico cassireriano, mostrando primeiramente a importância assumida pela mencionada tese em dois de seus principais expoentes (Frege e Russell) e, em segundo lugar, a crítica de Cassirer a estes e sua defesa a Dedekind. Em seguida retomaremos o papel desempenhado pelos predecessores de Cassirer em Marburgo (Cohen e Natorp) e seus inovadores Método transcendental e Lógica transcendental dentro do logicismo sui generis de nosso autor.

Palavras-Chave: Logicismo. Neo-Kantismo marburguês. Epistemologia juvenil de Cassirer. 


\section{Introdução}

In its most elementary form, the logicist thesis claims that mathematics, be all of it or part of it, can be reducible to logic. And initially that means that the first one is part of the second. Some other results of this assumption would be such as:

(i) the fundamental concepts of mathematics (e.g., the numbers) can be defined throughout logical concepts;

(ii) and its theorems can be proved throughout logical axioms and inference rules.

Although the veracity of this primary definition on the logicist thesis, there are, at very least, two interesting features for further reflections, namely, on the one hand there were no unanimous opinion around the thesis, but on the contrary: the thesis were take into account very differently by several philosophers which intended to work with it; and, on the other hand, strictly related to this first difference, the second aspect concerns the kind of logic defended by each one of those philosophers.

Exemplifying: Frege and Russell were two thinkers that defended this thesis. Now, although be without question to affirm that, it is not correct to say that both agree or defend the same kind of logicism. In Frege's ${ }^{1}$ case is affirmed that such thesis is valid, but only in the case of Aritmetics, not considering, thus, that Geometry would be also reducible to logic (and this claim was defended by the philosopher already in his doctoral dissertation, Über eine geometrische Darstellung der imaginären Gebilde in der Ebene, 1873). Russell's ${ }^{2}$ case is quite different: he defended a kind of logicism in which all mathematics (and that means, both Aritmetics and geometry) can be reducible to logic.

Perhaps less known than these two, Cassirer was another philosopher which defended the logicist thesis in this moment of history. ${ }^{3}$ However, he does not defend

\footnotetext{
${ }^{1}$ See in his Grundlagen der Arithmetik (GA), 1884, specially §§ 90-91.

2 See the first chapter of his Principles of Mathematics (PoM), 1903.

${ }^{3}$ In this moment, i.e., $19^{\text {th }}$ century, a lot of changes occurred in the in the field of philosophy and in the field of sciences. A lot of things could be said about that, but since this is not our main task here, let us make a brief commentary on the famous methodological distinction between natural sciences (Naturwissenschaften) and sciences of spirit (Geisteswissenschaften), which was operated by W. Dilthey who offered an epistemological justification for such distinction. The distinction between the Naturwissenschaften and the Geisteswissenschften - See DILTHEY (1883) - resumed by Cassirer himself in his Essay on Man (1944), puts philosophy in a delicate position. If for a long time Philosophy had reach the status of the most fundamental discipline of all, through the emancipation of the particular disciplines from its jurisdiction - and let us remember that from that time those same disciplines are possessing their own research methods and objects - what still remains for philosophy? In this sense, one of the day's tasks to be accomplished at that time will be precisely this one: to restore the positive relationship between philosophy and science. Facing these problems, the Neo-Kantian movement would emerge and would accept this difficult challenge of restoring the positive dialogue between philosophy and science. Lastly, also in regarding to this, take into account that Cassirer, in the first volume of his Philosophy of symbolic forms (1923), notes this problem concerning the applicability of the important results achieved in the field of natural sciences, worked by him in his book Substanzbegriff und Funktionsbegriff - whose major concern in the field of logic, mathematics and natural science is indubitable - to the field of the Geisteswissenschften.
} 
it like Frege or Russell did. Accordingly we have said previously, one of the main reasons which underlie this difference between than concerns mainly because of Cassirer's conception of logic, whose differs largely from his contemporaries (that is, Frege and Russell). In this particular, his influences came directly from his predecessors in Marburg.

But the differences between Frege and Russell, from a part, and Cassirer, from another, does not stop there. Another feature to be fought by Cassirer rests on that aspect recognized later as "mathematical Platonism". Roughly speaking, in this theory is defended the thesis that numbers exist in an abstract way, independent of us. This factor would be contested by Cassirer in virtue of important claims supported by a remarkable figure of those times, namely, the mathematician Richard Dedekind. The role played by his paper, Was sind und was sollen die Zahlen (1888), was of great importance in Cassirer's 1910 essay, Substanzbegriff und Funktionsbegriff. ${ }^{4}$ In Dedekind, the philosopher of culture found good arguments to support his criticism against on Frege and Russell. His basic argument against these two concerns the claim that numbers instead of being rather than conceived while things (as a Platonic would defend), they must be conceived as relations. As we shall see in the following lines, in the end, this particular conception of logicism was a sort of defense on what we call these days in mathematics as structuralism.

Lastly, the objective of our paper is twofold. On the one hand, we aim to expose Cassirer's critique, especially to Frege and Russell and, on the other hand, to explore his sui generis logicism. To fulfill these objectives, the chapter II, 'The concept of number', of his first important book, ${ }^{5}$ Substanzbegriff und Funktionsbegriff (1910), will be the basic text for the discussion. In it, Cassirer makes his numerous mentions, critiques and interpretations to those philosophers whose he is debating at this moment, e.g., Frege, Russell, Dedekind, the Neo-Kantians of Marburg, and the other important names on the debate.

\section{Background of the logicist thesis: Kant and his foundation of Mathematics}

In the beginning of the $19^{\text {th }}$ century, one of the most common foundation of mathematics was founded in the philosophy of Immanuel Kant, in which played a central role his refined theory of pure intuition. Roughly speaking, and according to the requirements presupposed by Kant's mature epistemological program, in this author is defended that is necessary to appeal to the pure intuitions of space (in the case of Geometry) and time (in the case of Arithmetic) to ensure the grounds of the mentioned discipline. In this way, Kant believes that the procedure in a mathematical demonstration is made from the construction of its concepts as far as the corresponding intuitions are provided.

While it is undeniable the importance value given by the Kantian foundation of mathematics, a strong and promising competitor was rising in the philosophical

\footnotetext{
${ }^{4}$ Before his classical essay of 1888 , and even more, before Frege himself, Dedekind, in 1872, with his Stetigkeit und Irrationale Zahlen, begins to work in his on logicist project. However, we will not enter in this subject. On it see RECK (2003), (2013, a) and (2013, b).

${ }^{5}$ We find in Cassirer's 1910 essay a sort of synthesis of his firsts important hints founded in some books he had published earlier, namely, his Kant und Moderne Mathematik (1907) and the first and second volume of his major Das Erkenntnisproblem in der Philosophie und Wissenschaft der neueren Zeit $(1906,1907)$.
} 
context of the time, having as one of its most important aims to ground this discipline differently than the author of the Critique of Pure Reason did, using in an exclusively way just logical threads, as we said above. The tour de force operated by many authors in this collective effort of many hues, from Bolzano ${ }^{6}$ to Russell, in this new project, was a remarkable event.

However, if this entire new web around this strong anti-intuitionist current in the foundations of mathematics dates back to a certain idea of logical fundaments, then we must question ourselves what was the logic underlying in that specific context, in order to fulfill such purpose; moreover, it must be clarified what were the differences between this new logic and that one held by Kant. In order to fulfill such task, let us take into account Frege's case.

\section{Frege}

One of the most important steps towards this revolution in the field of logic after Aristotle was made by Frege, throughout his theory of quantification. With it, syllogistics is totally renewed, providing logic a totally new and powerful apparatus. One of the changes proposed by him concerns the interpretation of sentences such as "A is B" no longer in terms of subject and predicate, but in terms of function and argument, i.e., reinterpreting such sentences as the fulfillment of a function through a certain argument. ${ }^{7}$

Moreover, another point that worthy the mention in Frege's philosophy is relative to the most remarkable characteristic of his logicist program, namely, his foundational ${ }^{8}$ project of reducing arithmetic to logic. ${ }^{9}$ Hence, further than the use of this new and refined logical apparatus - which was of great importance, indeed Frege's program was, in its essence, epistemological. In this way, the ambition of his project in Die Grundlagen der Arithmetic is, mutatis mutandis, as bold that one undertaken by Kant's Critique of Pure Reason; that means that their interest wasn't so distant after all, inasmuch as both works are inserted in the context of a same philosophical tradition, i.e., epistemology. ${ }^{10}$

It is clear that each answer to solve the problem concerning the epistemological grounds of arithmetic is different. And more than that, in Frege's

\footnotetext{
${ }^{6}$ In 1810 Bolzano published his Beyträge zu einer begründeteren Darstellung der Mathematik. In its apendix, Über die Kantische Lehre Von der Construction der Begriffe duch Anschauungen, this commitment against Kant's intuitionistic foundation is explicit. As we have said, Besides Bolzano's case a lot of others philosophers in this moment worked on this moment and more, they have influenced thinkers like Frege. Just to have a clue of names, take into account these three: Johann Friedrich Herbart (1776-1841), see his Allgemeine Metaphysik, 1828-29; Friedrich Adolf Trendelenburg (1802-1872), see his Über Leibnizens Entwurf einer Allgemeinen Charakteristik, 18571867); Hermann Lotze (1817-1881), see his Logik, 1874. On the influence of Herbart and Lotze on Frege see GABRIEL (2001), HEIS (2013) respectively.

${ }^{7}$ Thus, the sentence "All men are mortal" is now considered in following way: "For all $x$, if $x$ is men, then $x$ is mortal".

${ }^{8}$ We will see that this was not a problem in Cassirer's philosophy.

${ }^{9}$ Since his Begriffsschrift (1879), passing by Die Grundlagen der Arithmetik (1883), and finally in the two volumes of his Grundgesetze der Arithmetik (1893-1903), Frege's efforts aiming to show that the basic laws of arithmetic can be derived from the laws of logic was present explicitly.
}

10 On an interpretation of an "epistemologist Frege" see SLUGA (1980), especially the chapter II. 
proposal we find one change which would implies in the revision on one of the most important thesis found in Kant's Critique of Pure Reason: the judgments of arithmetic aren't synthetic a priori, but analytics. And that's because:

1. Although the starting point of Kant and Frege be the same, since both belief that the judgments of arithmetic are informative ones (and that means that they are not tautologies), the notion of analyticity in Frege differs from the Kantian homonymous.

2. This differentiation occur by the fact that Frege does not defend the thesis, like Kant did, that the analytical sentences are merely explanatory or trivial, in which there is just an expression of identity between the terms, but, instead, in them there are also accumulation of knowledge.

3. What is at stake at this point is the status that each one of them assigns to logic: while Kant gave logic a very restricting character, ${ }^{11}$ and that means concretely that logic is propaedeutics to the sciences ${ }^{12}$ (namely: arithmetic, geometry and physic), for Frege logic plays a much more decisive and foundational role.

4. Moreover, for Frege analyticity actually deals with the demonstrative reasons that support inferences; that means that analyticity is no longer, as Kant once believed, exclusively dealing with the relations between subject and predicate.

5. Finally, arithmetical concepts can be defined by logical concepts (e.g., numbers) and other basic notions of this discipline can be defined accurately taking into account exclusively the notions of logic. Therefore, the arithmetical theorems are proved by means of logical axioms and inference rules, leaving out whatever kind of intuitionist approach.

\section{The definition of number in Frege and Russell}

According we have said previously, Russell also defended the logicist thesis. However, we said as well that his kind of logicism differs from Frege's, highlighting that one central difference between them concerns the range of its domains: the English philosopher believed that both arithmetic and geometry were part of logic, differently of what Frege claimed. Although is important to bear in mind this factor, it is not our task here to provide an accurate account in their positions on the logicist thesis - because this would lead us to a new myriad of problems -, but only to resume the specific point of Cassirer's critique, elucidate it and to explain what it presupposes. Hence, in order to fulfill such proposes the aspects which both Frege and Russell accept and Cassirer criticized are the following:

\footnotetext{
11 See Kant's famous words on his Preface to the second edition of Critique of Pure Reason (KrV, B VIII-X).

12 The concept of science and the disciplines which fulfill such criteria in Kant's context are decisive here: science is universal and necessary, and even more, cumulative knowledge, i.e., which produces new knowledge. And this kind of knowledge is founded in Physic, arithmetic and geometry. As longer as logic deals only as an Organon, it can't be a science, in a strong sense.
} 
1. Their notion of number: both understand that numbers are the class of all classes of the same cardinality. Thus, the number 1 may be defined as the class of all unit classes; 2 as the class of classes of all pairs, and so on. ${ }^{13}$

2. Their 'Platonism': both authors support the thesis that numbers are dealing in some way with objects, which are some sort of abstract objects. Contrary to this defense, we will see that Cassirer considers that the numbers are just systems of relations.

\section{Cassirer's critique and his sui generis logicism}

At first sight it is not wrong to affirm that the starting point of Cassirer, Frege and Russell is the same, as far as they believed that:

a. is not possible that arithmetic be empiric;

b. that arithmetic can't depend on the pure intuitions in its grounds;

c. that logic is the discipline in charge for such task. Cassirer even makes clear his positive position with regard to this new fusion between the two disciplines, proposed by his predecessors.

In Substanzbegriff und Funktionsbegriff Cassirer notes that, adding some important features to his project:

The development of scientific arithmetic in the last decades is characterized by the increasing demand for the deduction of the concept of number, in its full important, from purely logical premises. The science of space seems to belong to intuition, or perhaps even to empirical perception. On the other hand, the thought gains acceptance that all determinations of numbers are to be grounded, without any appeal to sensible objects or any dependence upon concrete measurable magnitudes, 'by a finite system of simple steps of thought.' In this deduction of arithmetic out of logic, however, the latter is presupposed in a new form (CASSIRER, 1910. SF. P. 35) ${ }^{14}$

It is of particularly interest the final lines of this quotation, in which Cassirer begins to withdraw himself from his contemporaries and begins to consider a whole new group of authors which had influenced him in his logicist program.

\footnotetext{
${ }^{13}$ See Frege's GA, specially $\S 68$; and see Russell's PoM, Chapter XI, specially the page 116.

14 „Die Entwicklung, die die wissenschaftliche Arithmetik in den letzten Jahrzehnten genommen hat, ist dadurch charakterisiert, daß schärfer als je zuvor die Forderung hervortrat, den Zahlbegriff seinem vollständigen Gehalt nach aus rein logischen Prämissen abzuleiten. Die Wissenschaft des Raumes schien der Anschauung, schien bisweilen selbst der empirischen Wahrnehmung anheirnfajlen zu sollen: um so energischer aber kam nunmehr der Gedanke zur Geltung, daß alle Bestimmungen der Zahl sich ohne jede Berufung auf sinnliche Objekte, ohne jede Anlehnung an konkrete meßbare Größen „durch ein endliches System einfacher Denkschritte" begründen lassen müssen. In dieser Herleitung der Arithmetik aus der Logik aber wird diese selbst bereits in einer neuen Gestalt vorausgesetzt" (CASSIRER, 1910, P. 46).
} 


\subsection{Cassirer against the conception of classes}

In Substanzbegriff und Funktionsbegriff Cassirer initiates his argument against Frege and Russell as follows: it is not necessary that the number 2, for example, be considered as the class of all classes of pairs.

According to Cassirer, the number 2 is no more than the successor of 1 and the predecessor of 3 . Thus, the philosopher parts already from a different principle from his opponents, inasmuch as he takes into account the natural numbers as essentially ordinals, not cardinals. The author's words are very clear:

The specific meaning of 'four' or 'seven' could never result from the bare placing together of any number of groups of 'fours' or 'seven' elements; the individual groups must first be determined as ordered sequences of elements, thus as numbers in the sense of the ordinal theory. The 'how many' of the elements, in the ordinary sense, can be changed by no logical transformation into a bare assertion concerning 'just as many'; that remains an independent problem of knowledge. Consideration of this problem, however, leads back to a deeper opposition in method between the two interpretations of number. It is a fundamental characteristic of the ordinal theory that in it the individual number never means anything by itself alone, that in it the individual number never means anything by itself alone, that a fixed value is only ascribed to it by its position in a total system. (CASSIRER, 1910. SF. P. 48). ${ }^{15}$

Now, we already know that Cassirer does not seem convinced with the proposal of Frege and Russell and criticizes them in 1910. However, the content of his critique is not something new at the context of debate in which this work was conceived. Actually it is more a deepening of certain good ideas, which he believed to be good, founded in the positions of Dedekind, Cohen and Natorp.

\subsection{Dedekind and the concept of simply infinite system}

Cassirer's basic idea that numbers are structures has its origins in Dedekind's thought. Accordingly the mathematician, such conception of number presupposes another important concept in his mathematical theory, namely, that of simply infinite system, i.e., an infinity collection whose structure can be graphically represented as a number line, like in this case:

15 „Die spezifische Bedeutung der „Vier“ oder der "Sieben“ kann niemals aus der bloßen Nebeneinanderstellung noch so vieler Vierer- oder Siebenergruppen resultieren: es sei denn, daß schon zuvor die einzelnen Gruppen als bestimmt gegliederte Folgen von Elementen, also als Zahlen im Sinne der ordinalen Theorie, erfaßt worden sind. Das „Wieviel" der Elemente im gewöhnlichen Sinne läßt sich durch keine logische Umdeutung in eine bloße Aussage über das ", Gleichviel" verwandeln; es bleibt als selbständige Frage und Aufgabe der Erkenntnis zurück. Die Betrachtung dieser Aufgabe aber führt zu einem tieferen methodischen Gegensatz zurück, der zwischen den beiden Auffassungen der Zahl besteht. Es ist die Grundeigentümlichkeit der ordinalen Theorie, daß in ihr die Einzelzahl niemals etwas für sich allein bedeutet, daß ihr nur als Stelle im Gesamtsystem ein fester Wert zukommt“" (SF. CASSIRER, 1910, P. 52). 


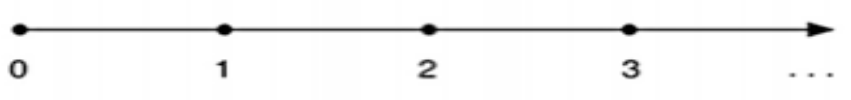

Figure 1: representation of a simply infinite system

Dedekind affirms that numbers are positions or structures on this in this infinite system. In other words: all essentials properties of a particular number are relations properties between this and another (natural) number. Moreover, this claim presupposes the famous Dedekind/Peano axioms, in which are expressed important conditions, such as:

1. The structure has a privileged position, called ' 0 ';

2. Every position has a successor in the structure;

3. ' 0 ' is not the successor of any position in the structure;

4. Every position has no more than one successor;

5. The validity of the principle of induction.

Accepting Dedekind results in his Was sind und was sollen die Zahlen, Cassirer reinforces his on position saying:

What is here [that is, in Dedekind's work] expressed is just this: that there is a system [...] whose content is exhausted in their mutual relations. The "essence" of the numbers is completely expressed in their positions. (CASSIRER, 1910. SF. P. 39 - Our emphasis) ${ }^{16}$

Moreover, Cassirer believes that from this point of view another positive aspect would appear. Such positive point goes directly against one import assumption of Frege and Russell, namely: once numbers are structures, there is no need to support a theory which defends an ontological account ${ }^{17}$ of numbers. ${ }^{18}$

\footnotetext{
16 „Was hier zum Ausdruck kommt, ist eben dies [...] deren gesamter Inhalt in ihren gegenseitigen Beziehungen erschöpft ist. Die „Essenz" der Zahlen geht in ihrem Stellenwert auf." (CASSIRER, 1910, P. 51).

${ }^{17}$ And that's because, for Dedekind numbers are "free creations of the human mind; they serve as a means of apprehending more easily and more sharply the difference of things. It is only through the purely logical process of building up the science of numbers and by thus acquiring the continuous number domain that we are enabled accurately to investigate our notions of space and time by bringing them into relation with this number-domain created in our mind" (DEDEKIND, 1888. Was sind und was sollen die Zahlen. Preface. P. VII-VIII).

18 To be fair, Cassirer actually does not give an appropriate account on some important concept and its distinctions between Frege and Russell. For instance: the concept of extension in Frege and the concept of class in Russell. What seems to happen is that he has one clear distinction between Dedekind's position (and his structuralism), from a part, and that one of Frege and Russell (with the notion of class), from another.
} 
Cassirer's choice for Dedekind's view instead of Frege and Russell is not made by mere change, but rather it is a strategic decision. Simply, he opts for a functional theory of knowledge rather than a theory of substance - and this is extremely important to his epistemological project.

Hence, instead of grasping a particular number, and taking into account that numbers are, as Cassirer said, "terms of relations, and as such can never be 'given' in isolation but only in an ideal community with each other" (CASSIRER, 1910. SF. P.36), ${ }^{19}$ actually we grasp the whole number structure.

\subsection{Remarks on Hermann Cohen, Paul Natorp and the origins of the neo- Kantianism of Marburg}

We said at the beginning of this text that the kind of logic that each author possess somehow, reflect in the way in which they take into account the logicist thesis. And yet, we said that at this moment in history of philosophy logic has undergone decisive changes that allowed the execution of tasks before unimagined.

Now, despite the fact that Cassirer was part of this profitable time and, more than that, he was aware of these achievements, he is not a follower of this new tradition, but of another one. His logic is not the same indorsed by those authors responsible for have started and developed the work of what we now call by classical logic. Actually, he was the prosecutor of a movement in which had great importance in his predecessor of Marburg.

\subsubsection{Transcendental Method, Transcendental logic and the project of Critique of Knowledge in SF}

Perhaps the notions of 'Transcendental Method', 'Transcendental logic' and the project of 'Critique of Knowledge' are the most important ones at present moment, if we want to understand what meant this audacious project by the neoKantians of Marburg, whose Cassirer's figure represented its culmination. In them we can find the presuppositions which the philosopher based his criticism on Frege and Russell.

1. Transcendental method, transcendental logic and its application: the basic idea of Cohen, ${ }^{20}$ who inaugurates the 'transcendental method', claims that philosophy, must start from the Faktum of science and, from it, to reflect on its conditions of possibility. ${ }^{21}$ In these terms, there is no place for an investigation on the foundations or a revisionist approach of science. Mathematics and physics are the paradigmatic subjects in this context, and therefore the

\footnotetext{
19 „Sie sind Relationsterme, die niemals losgelöst, sondern nur in idealer Gemeinschaft miteinander "gegeben“ sein können." (CASSIRER, 1910, P. 46).

${ }^{20} \mathrm{Cf}$. on this theme in Cohen's book of 1877, Kants Bregründung der Ethik, especially the pages 2425.

21 If we take other approaches that time, namely: the speculative method of Hegel and the psychological method, we see that the transcendental method is a reaction to both. In it, philosophy would no longer start from metaphysical speculation or either with observations of human psychology (whether by introspection, is the physiology), but only from the Faktum of science.
} 
Faktum we must reflect is its conditions of possibility. Also according to the neo-Kantian view, and Cassirer endorse this position, the traditional logic (i.e., the one that Cassirer attributes to Frege and Russell) can't do this. And the appropriate logic for this purpose is the neo-Kantians 'transcendental logic', which would focus on the analysis of the conditions of possibility of sciences.

2. Substanzbegriff und Funktionsbegriff - Untersuchungen über die Grundfragen der Erkenntniskritik. This is the full title of the work of 1910; and in it Cassirer:

a. contrasts two views in Philosophy: one in which is neglected the epistemic conditions of various types of knowledge (Substanzbegriff); and one that recognizes such conditions (Funktionsbegriff). He opts for the second one.

b. From his historical approach in $S F$, Cassirer believed to have assembled the three main pillars of his time:

1. the methodology of the exact sciences of the nineteenth century;

2. the new logic of Frege and Russell and

3. the neo-Kantians presuppositions.

c. The objects of his critique 22 are the abstractionist theories of concept formation (Begriffsbildungen), in which they claim to be able to form a concept without the use of other or of any fact (and Frege and Russell would be situated in that hall, inasmuch the conceived numbers while 'things'). The two basic steps made by Cassirer in his critique to them are:

1. first he makes his attack on the tradition logic, in chapter I;

2. Then, in chapter II, he makes his defense of Dedekind instead the views of Frege and Russell. For Cassirer, they maintain their positions in a substantial theory of knowledge (or specifically: in a theory of number in which the number is some kind of thing, as we noticed), instead of, like Dedekind did, claimed for a functional theory (or specifically: a theory of number in which the number is take into account while a structure. In the following chapters of his book, Cassirer applies this same methodology to the cases of geometry and physics.

d. Finally, Cassirer's enterprise is fulfilled thanks to another important vindication, namely, his Erkenntniskritik. According the author:

The task of Erkenntniskritik consists in this, to go back from the unity of the general concept of the object to the manifold of necessary and sufficient conditions that constitute it. In this sense the thing that cognition calls its 'object' is resolved into a web of relations that are themselves held together through the highest rules and principles. (CASSIRER, 1927. Erkenntnistheorie nebst den Grenzfragen der Logik und Denkpsychologie. P. 13)

\section{Concluding Remarks}

We intended here to show what Cassirer meant in his sui generis logicism, taking into account his contrasts with two authors: Frege and Russell.

${ }^{22}$ See the Preface of SF. 
We note that although the philosopher of culture accepted that numbers may be deductible logic - and this would place him, in a broad sense, according to his opponents - he does not accept Frege's and Russell's approach of assuming that the number is a thing, because this would shock the basic proposal of his Substanzbegriff und Funktionsbegriff, i.e., a 'functional theory of knowledge'.

For Cassirer, this logical foundation means that can be dissolved in its relations. We also show that his criticism of the two philosophers have as assumptions Dedekind's structuralism, on the one hand, and the application of the transcendental method of neo-Kantians of Marburg, on the other.

Assuming the position of the mathematician, Cassirer would have found arguments compatible to his project in 1910. At this period, Cassirer knew the Russell's POM (1903). In consequence, the quarrel between both (Dedekind and Russell) was familiar to him. In this same text, ${ }^{23}$, the criticism that Russell does against Dedekind's notion of numbers as relations only strengthens Cassirer's position in favor of the German mathematician. The Transcendental method was the great epistemological inheritance of his master (Hermann Cohen). From it, the urgency of an investigation into the conditions of possibility on the Faktum of sciences is explicit. And mathematics is a particular case of this presupposition.

\section{Referências}

BEISER, F. After Hegel - German Philosophy 1840-1900. New Jersey: Princeton University Press, 2014.

BENACERRAF, P. and PUTNAM, H. Philosophy of Mathematics. Second Edition. Cambridge U. Press, 1983.

The Fate of Reason. German Philosophy from Kant to Fitche. Mass: Harvard University Press, 1993.

2014.

The Genesis of Neo-Kantianism. 1796-1880. Oxford University Press.

CASSIRER, E. Einstein's Theory of Relativity. [1921] Chicago: Open Court, 1923.

. Ensaio sobre o homem. [1945] São Paulo: Martins Fontes, 2000.

Cultura Económica, 1975.

Esencia y efecto del concepto de símbolo. México: Fondo de

Filosofia das formas simbólicas. Primeiro Tomo: A linguagem [1923]

São Paulo: Martins fontes, 2001.

Substance and Function [1910] Chicago: Open Court, 1923.

COHEN, H. Das Princip der Infinitezimal-Methode und seine Geschichte. Berlim. Ferd. Dümmlers Verlagsbuchhandlung. 1883

Kants Begründung der Ethik. Berlim. Ferd. Dümmlers

Verlagsbuchhandlung. 1887.

\footnotetext{
${ }^{23}$ See the $\S 242$ of PoM.
} 
Kants Theorie der Erfahrung. Berlim. Ferd. Dümmlers

Verlagsbuchhandlung. 1885.

COUTURAT, L. La logique de Leibniz. Paris: Félix Alcan, 1901.

Les Principles des Mathématiques. Avec un Appendice sur La Philosophie des Mathématique de Kant. Paris, Félix Alcan, 1905

DILTHEY, W. Introdução às ciências humanas. [1883]. Forense Universitária, 2010.

DUMMETT, M. Truth and other Enigmas. Harvard U. Press, 1978.

FREGE, G. Die Grundlagen der Arithmetik. BRESLAU. Verlag von Wilhelm Koebner. 1884.

FRIEDMAN, M. A Parting of Ways: Carnap Cassirer and Heidegger. Chicago: Open Court, 2000.

FRIEDMAN, J. Tyler and LUFT, Sebastian: The Philosophy of Ernst Cassirer: a Novel Assessment. Books by Marquette University Faculty. Book 225, 2015.

Gabriel, G.. 'Existenz- und Zahlaussage. Herbart und Frege', In: A. Hoeschen and L. Schneider, eds., Herbarts Kultursystem, Würzburg: Könighausen \& Neumann, pp. 149-162, 2001

GRIFFIN, N (ORG.). The Cambridge Companion to Bertrand Russell. Cambridge U. Press, 2003.

GUYER, P. Guyer: Absolute idealism and the rejection of Kantian dualism, In: AMERIKS, K. (ORG.) The Cambridge Companion to German Idealism. Cambridge U. Press, 2005. 37-57.

HEIS, J. "Critical philosophy begins at the very point where logistic leaves off": Cassirer's Response to Frege and Russell. In: Perspectives on Science, vol. 18, no. 4, by The Massachusetts Institute of Technology. 2010. P. 383-408.

. 'Frege, Lotze, and Boole', in E. Reck, ed., The Historical Turn in Analytic Philosophy, London: Palgrave Macmillan, pp. 113-138, 2013.

KANT, I. Crítica da Razão Pura [1 $1^{\text {a }}$ Ed. 1781 - 2a Ed. 1787] Lisboa: Fundação Calouste Gulbekian, 1994.

KÖHNKE, K. The Rise of neo-Kantianism: German academic philosophy between idealism and positivism. [1986] New York, Cambridge University Press: 1991.

LANGE, F. A. Geschichte des Materialismus und Kritik seiner Bedeutung in der Gegenwart. Iserlohn: J. Baedeker, 1866.

MORMANN, T. From Mathematics to Quantum Mechanics - On the Conceptual Unity of Cassirer's Philosophy of Science (1907-1937). P. 31-63. In: Friedman, J. Tyler and LUFT, S. The Philosophy of Ernst Cassirer: a Novel Assessment. Books by Marquette University Faculty. Book 225, 2015.

NATORP, P. Die logischen Grundlagen der exakten Wissenschaften. Leipzig und Berlin Druck und Verlag von B. G. Teubner. 1910.

PORTA, M. A. G. Estudos Neokantianos. São Paulo: Loyola, 2011. 
PRINGE, H. B. Causalidad, invariancia y sistematicidad em el neokantismo de Ernst Cassirer. Est. Filos. Universidad de Antioquia, 2013. P. 109-127.

PULKKINEN, J. Russell and the Neo-Kantians. In: Stud. Hist. Phil. Sci., Vol. 32, No. 1, pp. 99-117, 2001.

RECK, E. 'Dedekind's structuralism: An interpretation and partial defense', In: Synthese, 137, 369-419. 2003.

. 'Frege's natural numbers: Motivations and modifications', In: M. Beaney and E. Reck, eds., Gottlob Frege: Critical Assessments of Leading Philosophers, Vol. III, London: Routledge, pp. 270-301. 2005.

. 'Dedekind's Contributions to the Foundations of Mathematics', In: Stanford Encyclopedia of Philosophy, pp. 1-32 (originally published in 2008, revised in 2011).

'Dedekind, structural reasoning, and mathematical understanding', In: B. van Kerkhove, ed., New Perspectives on Mathematical Practices, Singapore:World Scientific, pp. 150-173. 2009.

. 'Frege or Dedekind? On their relation, reception, and revival', In: E. Reck, ed., The Historical Turn in Analytic Philosophy, London: Palgrave Macmillan, pp. 139-170. 2013, a.

Frege, Dedekind and the origins of logicism. In: History and Philosophy of logic, 34:3, P. 242-265. 2013, b.

RICHARDSON, A.: “The Fact of Science' and Critique of Knowledge: Exact Science as Problem and Resource in Marburg Neo-Kantianism." Pp. 211-226. In: FRIEDMAN AND NORDMANN: The Kantian Legacy in Nineteenth-century Science. Cambridge, MA: MIT Press. 2006.

RUSSELL, B. A Critical exposition of the philosophy of Leibniz. Cambridge U. Press. 1900.

Principles of Mathematics [1903]. Routledge. 2010.

RYCKMAN, T. A. 'CONDITION SINE QUA NON?' Zuordnung in the earlies epistemologies of Cassirer and Schlick. In: Synthese Vol. 88, No. 1 pp. 57- 95, Jul. 1991. 